\title{
Efforts to Combat Wild Animals Trafficking in Brazil
}

\author{
Guilherme Fernando Gomes Destro, Tatiana Lucena Pimentel, \\ Raquel Monti Sabaini, Roberto Cabral Borges and Raquel Barreto
}

Additional information is available at the end of the chapter

http://dx.doi.org/10.5772/48351

\section{Introduction}

Wildlife trafficking, including the flora, fauna and their products and byproducts, is considered the third largest illegal activity in the world, after weapons and drugs trafficking. Considering only the wild animals trafficking in Brazil, it is estimated that about 38 million specimens are captured from nature annually and approximately four million of those are sold. Based on the data of animals seized and their prices, it is suggested that this Country deals with about two billion and five hundred million dollars a year [1].

The wildlife trafficking networks, like any other criminal network, have great flexibility and adaptability and join with other categories or activities (legal or illegal), such as drugs, weapons, alcohol, and precious stones. Their products are often sent from the same regions and have similar practices such as forgery, bribery of officials, tax evasion, fraudulent customs declarations, among many others [1].

In some cases, the criminals are infiltrated in public agencies to entice public officials and, in case of problems in the target Country, they can move with ease to other destination. Moreover, people involved can be easily replaced by others more efficient, reliable and qualified for the activity. This great power of mobility and changeability is one of the major problems to map the criminal networks and their local of action [2].

Although modern techniques has been used, around the world, to help the enforcement in the combat of illegal wildlife trade $[3,4,5]$, the trafficking structure still presents features in common with the set of network information, because it requires equipment that enables the continuous exchange of information on routes, on the most quoted animals at the black market, on new forms of fraud and on corruption pathways. The new technologies are more and more used to increase the possibility of success on criminal operations, either through the use of cell phones, computers to defraud documentation, or internet sales, among others [2]. 
According to the report of the National Network to Combating Wild Animal Trafficking [1], there are four methods that encourage the illegal trade in wild animal: (a) animals for zoos and private collectors, (b) for scientific use/ biopiracy, (c) for pet shops and (d) for products and byproducts.

However, it is known that identifying the site of capture isn't an easy task, because the locals where the animals are confiscated usually differs from where they were captured. Furthermore, the capture and the sale of wild animals and their byproducts are not concentrated in one only place and do not always follow the same destiny: the movement is intense, with many destinations. After being captured, the animals commonly pass through small and medium traffickers who make the connection with Brazilian and international large dealers, however, the animals can also be sold by internet, pet shops and illegal fairs [2].

Although the trafficking consequences are numerous, it is possible to group them into three main branches: (a) Sanitary, since illegal animals are sold without any sanitary control and can transmit serious diseases, including unknown ones, onto domestic breeding and people $[1,2,6]$; (b) economic/social, as the trafficking moves incalculable amounts of financial resources without bringing income to the public coffers [1]; and (c) Ecological, since the capture from nature done without discretion accelerate the process of extinction of species, causes damage to ecological interactions and loss of the genetic heritage. Moreover, the trafficking can also bring ecological damage arising from the introduction of exotic specimens, that, although acquired as pets, are being abandoned by their owners in various natural areas [1].

Illegal wildlife trafficking is an extremely lucrative crime with serious consequences yet relatively low penalties and few prosecutions [3]. Besides all the complicating factors inherent to the trafficking, the researchers of this subject are facing yet the lack of organized and systematized data and information [2]. In addition, the studies on trafficking and its impacts on biota are also scarce [7], what makes the task of systematization even more complex.

Thus, through this work, we presented a national view of the control and combat actions towards the wild animals trafficking in Brazil through the existing information at the corporative systems managed by the Brazilian Institute of Environment and Renewable Natural Resources - IBAMA. As specific goals, we aimed to:

- Historically evaluate the gradual development of the Brazilian environmental enforcement related to fauna;

- Map the Brazilian States where there are greater efforts against wild animals trafficking, as well as the most confiscated species;

- Evaluate the major forms of admission and destination of the wild animals present at the Rehabilitation Centers;

- List the main perspectives and recommendations of actions to combat wild animals trafficking in Brazil. 


\section{The enforcement for conservation of wild animals in Brazil}

For the preparation of this paper we used, primarily, historical information present in four information systems (Table 1), all managed by IBAMA. This information was compiled, systematized and analyzed together with literature data.

\begin{tabular}{|c|c|c|}
\hline System & Name & Objective \\
\hline SICAFI & $\begin{array}{l}\text { Recording, Levying } \\
\text { and Enforcement System }\end{array}$ & $\begin{array}{c}\text { Responsible for recording data and } \\
\text { information relating to environmental } \\
\text { enforcement activities performed by IBAMA } \\
\text { and partners institutions }\end{array}$ \\
\hline SISPASS & $\begin{array}{c}\text { Recording Passeriform } \\
\text { Amateur Breeders System }\end{array}$ & $\begin{array}{l}\text { Responsible for the control of the activity of } \\
\text { Amateur and Commercial Passeriform }{ }^{1} \\
\text { Breeders }\end{array}$ \\
\hline SISFAUNA & Fauna Management System & $\begin{array}{l}\text { Responsible for the management of wild } \\
\text { animals in captivity, including the emissions } \\
\text { of permits, stock control, domestic trade, } \\
\text { licenses issued and carried out transactions }\end{array}$ \\
\hline SISCITES & $\begin{array}{l}\text { System for the importation } \\
\text { and exportation of } \\
\text { specimens, biological stuff, } \\
\text { native and exotic wildlife } \\
\text { products and byproducts }\end{array}$ & $\begin{array}{c}\text { Controls the importation and exportation of } \\
\text { species listed in } \\
\text { the CITES } 2 \text { appendices }\end{array}$ \\
\hline
\end{tabular}

Table 1. Information systems related to wildlife and managed by IBAMA.

In Figure 1 we summarized data from the Wild Animals Rehabilitation Centers - CETAS, on all the confiscated wild animals placed there during eight years. The CETAS are responsible for receiving, identifying, marking, selecting, evaluating, recovering, rehabilitating and placing wild animals. Furthermore, they are important allies to the actions for the repression of trafficking because they provide relevant information about confiscated wild animals or from voluntary delivery.

As recommended by the Brazilian Environmental Policy and showed in Figure 1, the State supervision related to illegal wildlife, under the responsibility of the Environmental Military Police, has steadily increased in number and efficiency, thanks to ongoing efforts to decentralize responsibilities in the Country. Thus, IBAMA has been able to focus on major crimes, with significant results through the dissuasion of his actions. It is important to inform that in Brazil, the fines are applied per animal. So, due to that, Minas Gerais (which had the highest participation of environment military police) has the largest number of fines (Figure 2), but it doesn't reflect the absolute value. This happens because of the type of inspection that fights against the final receptors of wild animal traffic.

\footnotetext{
${ }^{1}$ IBAMA's Normative Instruction No 15/2010

${ }^{2}$ CITES: Convention on International Trade in Endangered Species of Wild Fauna and Flora (www.cites.org). The Brazilian CITES Management and Enforcement Authorities are represented by IBAMA.
} 


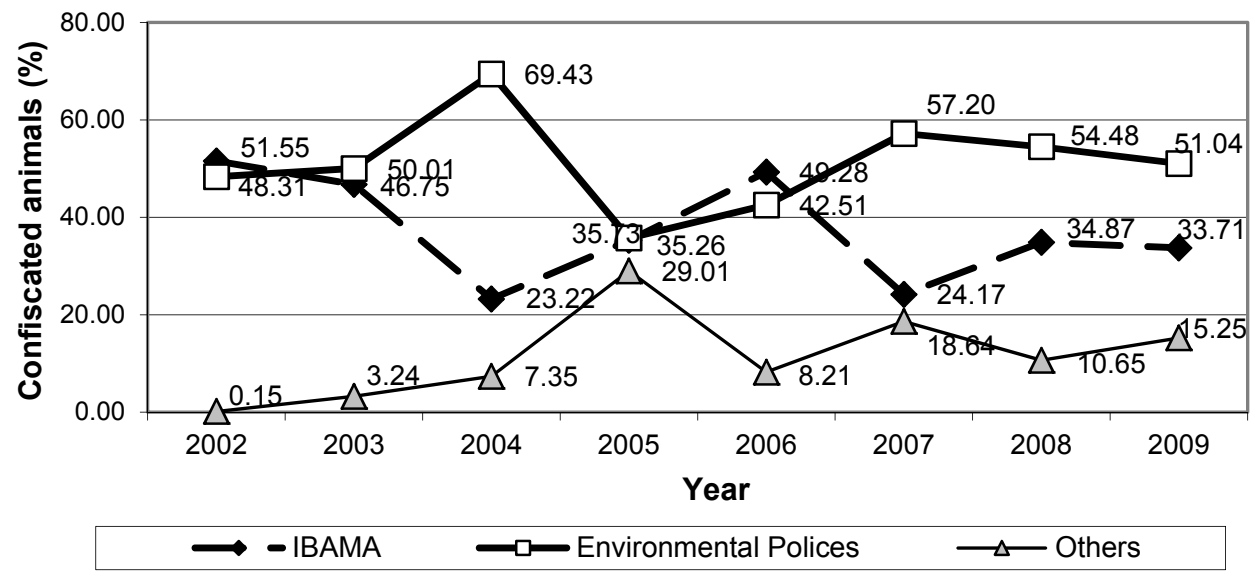

Figure 1. Number of confiscated wild animals received by CETAS

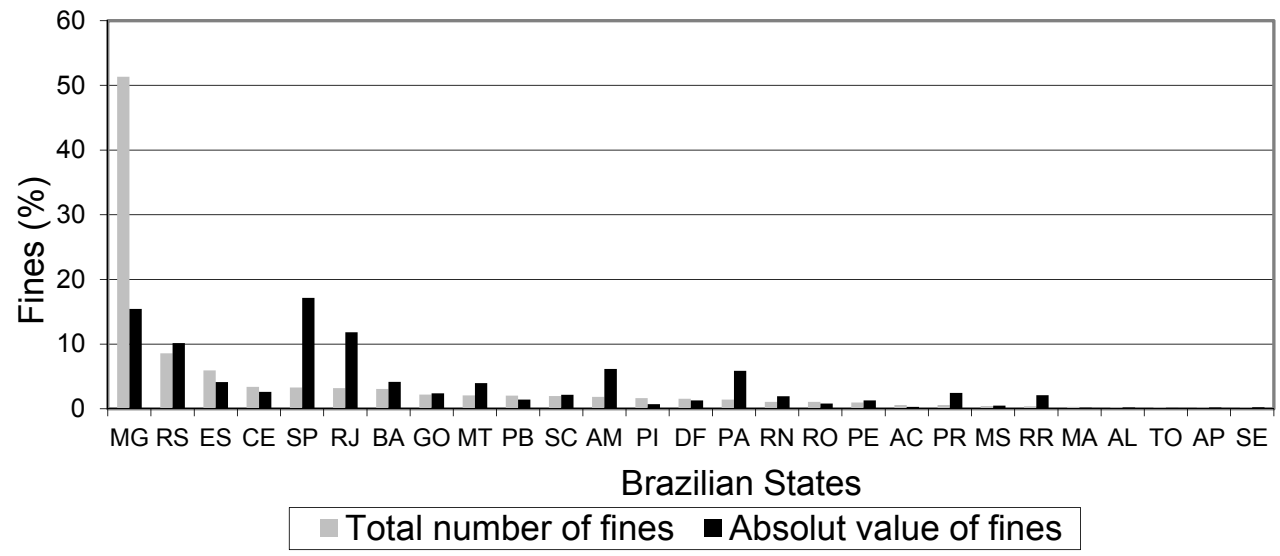

Figure 2. Percentage of Fauna fines per Brazilian State and their absolut value from 2005 to 2010.

In Figure 2, the distinction among each Brazillian State on the combat against illegal actions related to wild animals is clear. The States of Rio Grande do Sul (RS), Minas Gerais (MG), Espírito Santo (ES), São Paulo (SP) and Rio de Janeiro (RJ) were the ones with the highest numbers of fines applied between 2005 and 2010. The last four are located in the southeastern region, where is the demand from the majority of animals from traffic. The States of Sergipe (SE) and Tocantins (TO) emerged with the lowest numbers. The States with the highest absolute values applied in fines were São Paulo (SP), Minas Gerais (MG), Rio de Janeiro (RJ), Rio Grande do Sul (RS), Amazonas (AM) and Pará (PA) (both last ones are located in the rainforrest region and represent one of the main sites where some taxon are captured), unlike the States of Maranhão (MA) and Tocantins (TO), which had the lowest absolute number. 
We emphasize that the animals confiscated by Brazilian environmental agencies represent only a portion of the damage [8]. The task of estimating the amount of animals withdrawn from nature per year becomes even more difficult if we consider that the possession of a wild animal captured from nature in Brazil is a common practice, despite being prohibited by law. However, IBAMA's Department of Fish and Wildlife points out that the CETAS alone received in 2008 more than 60,000 animals and were destined more than 40,000 (Figure 4). We noticed, yet, that this number is still small. It happens because most of the animals confiscated in actions of inspection are released into the wild, due to the fact that they are still in savage condition.

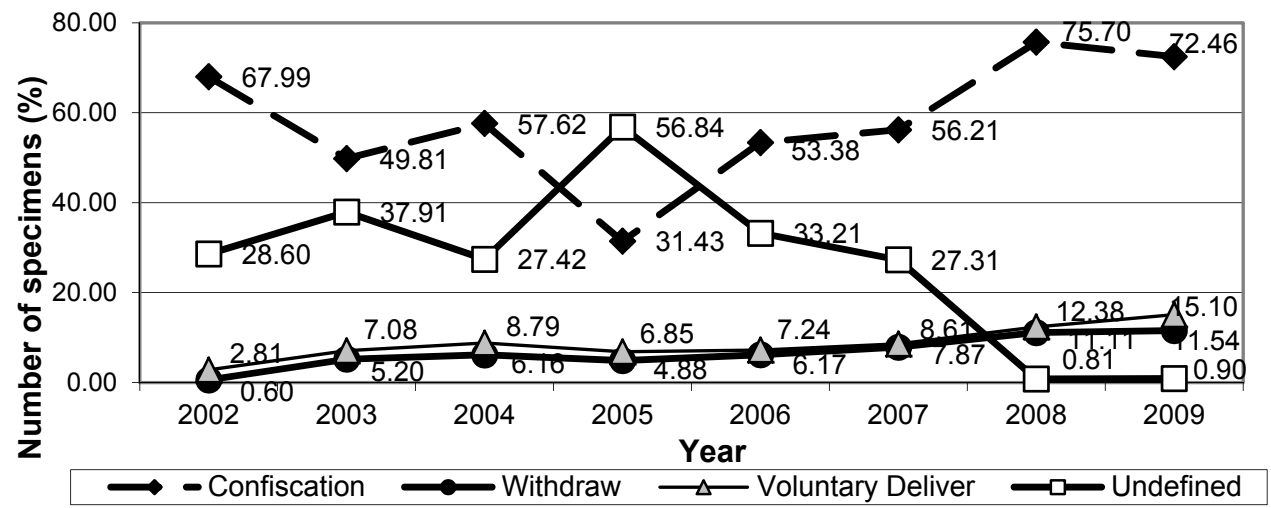

Figure 3. Number ofwild animals received by CETAS and their different forms of admission.

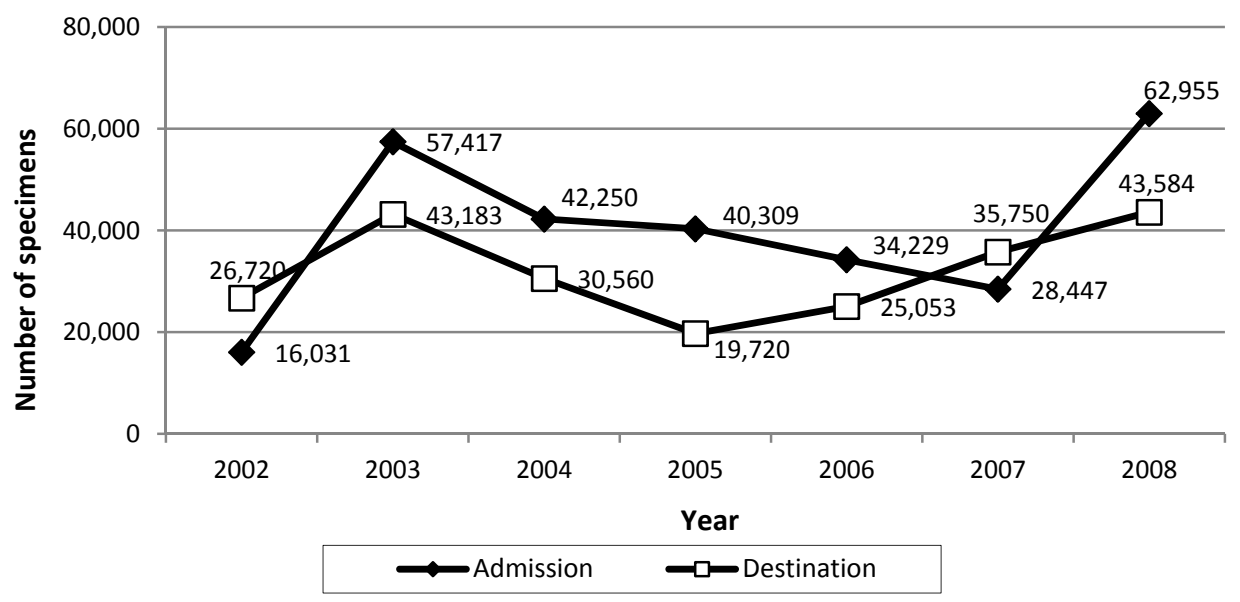

Figure 4. Relationship between admission and destination of specimens in CETAS between 2002 and 2008 , in absolute numbers. 
The Figure 5 and the Table 2 gather the destinations given to animals from CETAS, between 2002 and 2009. We observed that the releases, after the declining trend observed between 2004 and 2007, re-emerged as the main destination given to the confiscated animals in Brazil, reaching almost 23,000 specimens released into the wild in 2008. The placement in captivity, widely used in 2006 and 2007, has a lower incidence from 2008 on, with the publication of new normative instruments, which regulated the policy to native and exotic wild animals in captivity.

The number of deaths recorded in CETAS suffered variations over the sample period, but their values remained between 16 and 26 percent. The values of escapes/evasions remained constantly low if compared with the total number of destinations.

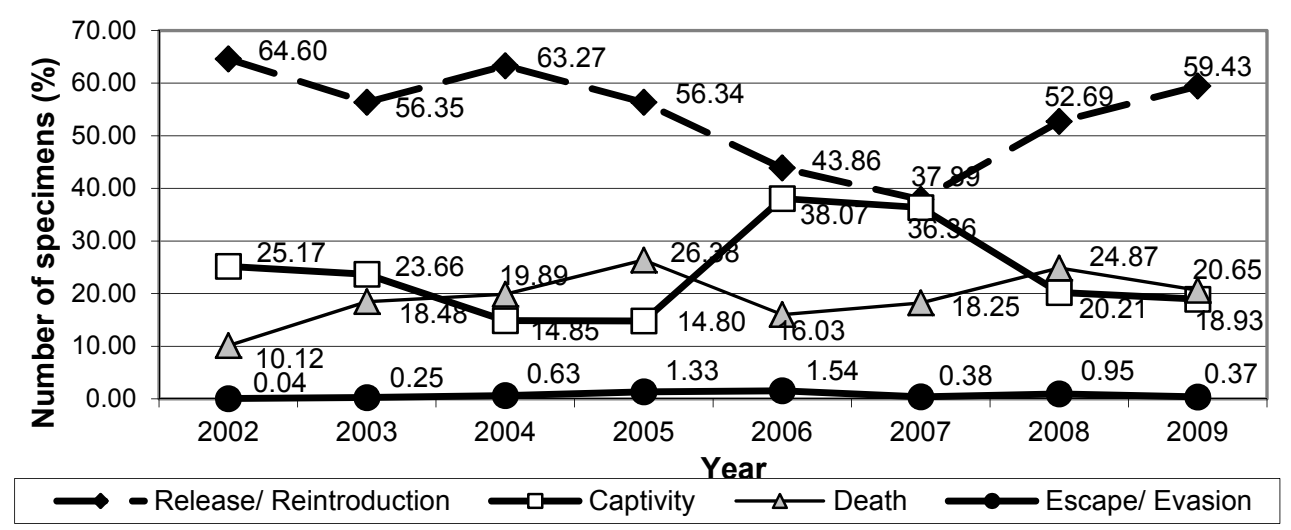

Figure 5. Destination of the animals from CETAS between 2002 and 2009.

\begin{tabular}{|c|c|c|c|c|c|}
\hline Year & Admissions & $\begin{array}{c}\text { Releases/ } \\
\text { Reintroductions }\end{array}$ & Captivities & Deaths & $\begin{array}{c}\text { Escapes/ } \\
\text { Evasions }\end{array}$ \\
\hline 2002 & 16,031 & 17,260 & 6,725 & 2,705 & 12 \\
\hline 2003 & 57,417 & 24,333 & 10,219 & 7,980 & 110 \\
\hline 2004 & 42,250 & 19,336 & 4,538 & 6,078 & 191 \\
\hline 2005 & 40,309 & 11,110 & 2,919 & 5,202 & 263 \\
\hline 2006 & 34,229 & 10,988 & 9,537 & 4,015 & 386 \\
\hline 2007 & 28,447 & 13,544 & 12,998 & 6,523 & 137 \\
\hline 2008 & 62,955 & 22,965 & 8,809 & 10,839 & 413 \\
\hline
\end{tabular}

Table 2. Number of specimens destined by CETAS between 2002 and 2008. 


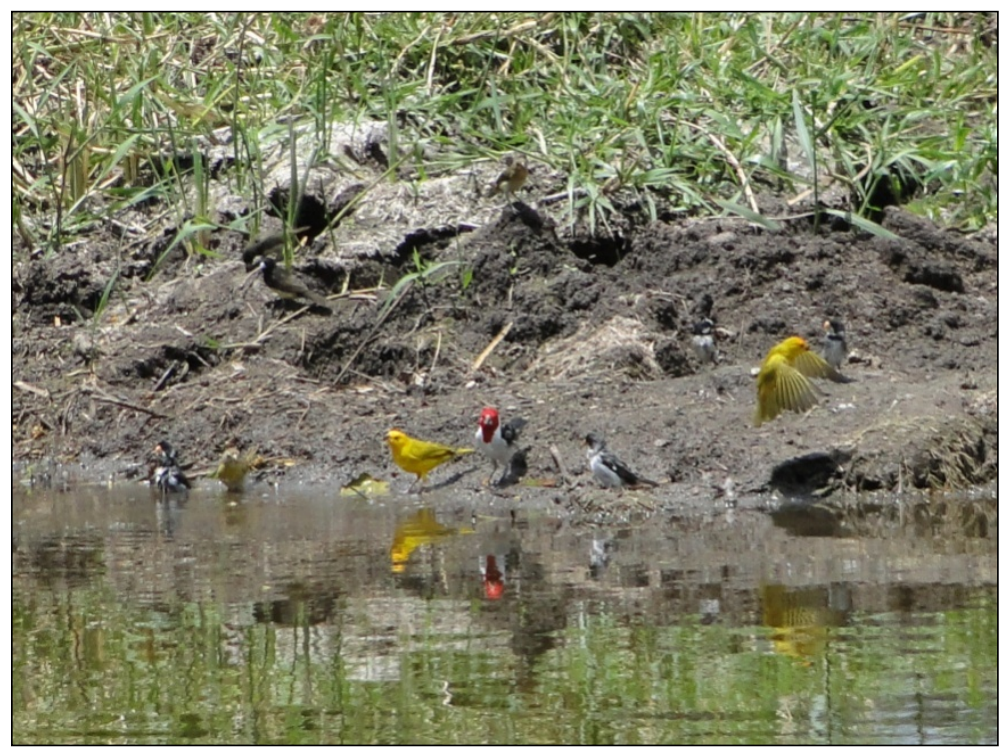

Figure 6. Released birds in Bahia (BA)

\section{The species of confiscated animals}

We found that the destination given to confiscated animals in Brazil is directly linked to the taxonomic class of animal (Figure 7). For Birds, the main form of destination was release into the wild (greater than 55\%), followed by placement in captivity and death. Release into the wild was also the main destination given to reptiles $(\sim 60 \%)$ and mammals $(\sim 45 \%)$. We also noticed that reptiles obtained a lower death rate, while the exotics animals remained in captivity $(\sim 60 \%)$.

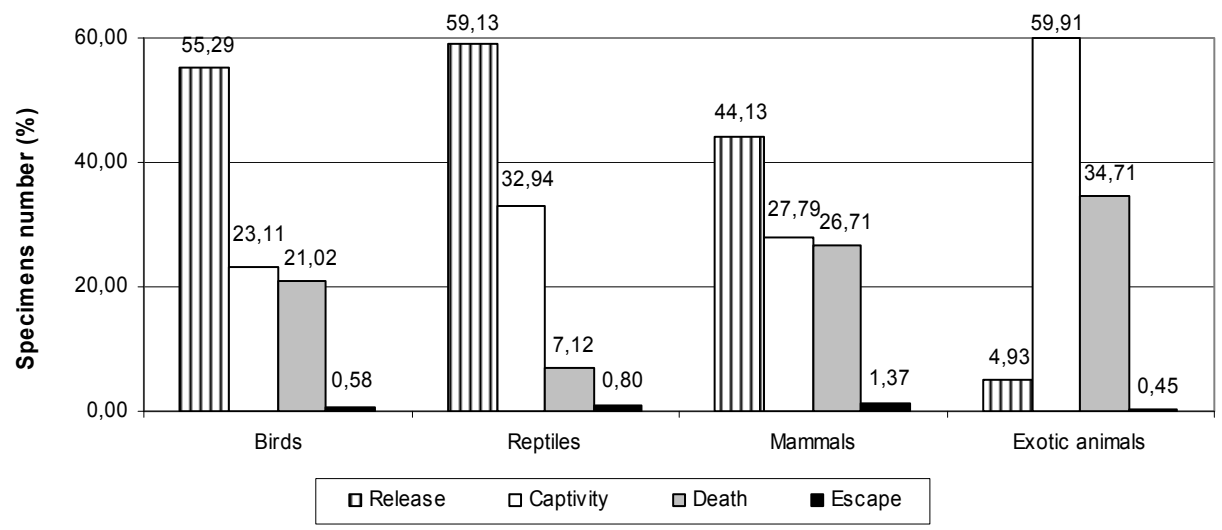

Figure 7. Destination of the animals from CETAS between 2002 and 2009, by taxonomic group. 
The Table 3 presents the amount of admission and destination of animals from CETAS. Birds represented $81 \%$ of admitted specimens and $82 \%$ of released ones, between 2002 and 2009. The Birds was also the group that obtained the largest number of deaths registered (86\%). In Australia and Asia, Reptilia was most targeted group of taxa for illegal trade,being also the most seized $[4,9]$.

\begin{tabular}{|l|c|c|c|c|c|}
\hline \multicolumn{1}{|c|}{ Group } & Entrance & Release & Captivity & Death & Escape \\
\hline Birds & 250,206 & 108,622 & 45,395 & 41,294 & 1,135 \\
\hline Reptiles & 34,835 & 17,198 & 9,581 & 2,072 & 233 \\
\hline Mammals & 17,936 & 7,233 & 4,554 & 4,377 & 225 \\
\hline Exotics & 4,577 & 44 & 535 & 310 & 4 \\
\hline
\end{tabular}

Table 3. Amount of specimens that entered and left the CETAS between 2002 and 2009.

We listed, in the Table 4, the 30 species most confiscated by IBAMA and accredited institutions between 2005 and 2009, according to SICAFI. The class Aves was the most representative $(80 \%)$, followed by Reptilia $(16.67 \%)$. The most significant families were Emberizidae (30\%), Thraupidae (13.33\%) and Podocnemididae (10\%). The most commonly confiscated species was Sicalis flaveola (Saffron Finch), followed by Saltator similis (Greenwinged Saltator) and Sporophila caerulescens (Double-collared Seedeater), (Figure 8).

\begin{tabular}{|c|c|c|c|c|c|}
\hline Classif & Type & Class & Family & Specie $^{3}$ & Common name \\
\hline $1^{\mathrm{o}}$ & $\begin{array}{l}\text { Wild } \\
\text { animal }\end{array}$ & Aves & Emberizidae & $\begin{array}{c}\text { Sicalis flaveola } \\
\text { (Linnaeus, 1766) }\end{array}$ & Saffron Finch \\
\hline $2^{\underline{o}}$ & $\begin{array}{l}\text { Wild } \\
\text { animal }\end{array}$ & Aves & Thraupidae & $\begin{array}{c}\text { Saltator similis } \\
\text { d'Orbigny \& } \\
\text { Lafresnaye, } 1837\end{array}$ & $\begin{array}{l}\text { Green-winged } \\
\text { Saltator }\end{array}$ \\
\hline $3^{o}$ & $\begin{array}{l}\text { Wild } \\
\text { animal }\end{array}$ & Aves & Emberizidae & $\begin{array}{c}\text { Sporophila } \\
\text { caerulescens (Vieillot, } \\
1823 \text { ) } \\
\end{array}$ & $\begin{array}{c}\text { Double-collared } \\
\text { Seedeater }\end{array}$ \\
\hline $4^{\mathrm{o}}$ & $\begin{array}{c}\text { Wild } \\
\text { animal }\end{array}$ & Aves & Cardinalidae & $\begin{array}{l}\text { Cyanoloxia brissonii } \\
\text { (Lichtenstein, 1823) }\end{array}$ & $\begin{array}{c}\text { Ultramarine } \\
\text { Grosbeak }\end{array}$ \\
\hline $5^{\mathrm{o}}$ & $\begin{array}{c}\text { Wild } \\
\text { animal }\end{array}$ & Aves & Emberizidae & $\begin{array}{c}\text { Sporophila angolensis } \\
\text { (Linnaeus, 1766) }\end{array}$ & \begin{tabular}{|c}
$\begin{array}{c}\text { Chestnut-bellied } \\
\text { Seed-Finch }\end{array}$ \\
\end{tabular} \\
\hline $6^{\mathrm{o}}$ & $\begin{array}{l}\text { Wild } \\
\text { animal }\end{array}$ & Reptilia & Podocnemididae & $\begin{array}{l}\text { Podocnemis expansa } \\
\text { Schweigger, } 1812\end{array}$ & $\begin{array}{c}\text { Giant South } \\
\text { American River } \\
\text { Turtle } \\
\end{array}$ \\
\hline $7^{o}$ & $\begin{array}{c}\text { Wild } \\
\text { animal }\end{array}$ & Aves & Icteridae & $\begin{array}{c}\text { Gnorimopsar chopi } \\
\text { (Vieillot, 1819) }\end{array}$ & Chopi Blackbird \\
\hline $8^{-}$ & Domestic & Aves & Phasianidae & Gallus gallus & Domestic \\
\hline
\end{tabular}

${ }^{3}$ Nomenclature according to the updated lists CBRO, 2011 (www.cbro.org.br) and SBH, 2011 (http://www.sbherpetologia.org.br) 


\begin{tabular}{|c|c|c|c|c|c|}
\hline Classif & Type & Class & Family & Specie $^{3}$ & Common name \\
\hline & animal & & & (Linnaeus, 1758) & Chicken \\
\hline $9^{\circ}$ & $\begin{array}{l}\text { Wild } \\
\text { animal }\end{array}$ & Aves & Thraupidae & $\begin{array}{c}\text { Paroaria dominicana } \\
\text { (Linnaeus, 1758) }\end{array}$ & $\begin{array}{l}\text { Red-cowled } \\
\text { Cardinal }\end{array}$ \\
\hline $10^{\underline{o}}$ & $\begin{array}{c}\text { Wild } \\
\text { animal }\end{array}$ & Aves & Emberizidae & $\begin{array}{l}\text { Sporophila lineola } \\
\text { (Linnaeus, 1758) }\end{array}$ & Lined Seedeater \\
\hline $11^{\mathrm{o}}$ & $\begin{array}{l}\text { Wild } \\
\text { animal }\end{array}$ & Reptilia & Podocnemididae & $\begin{array}{c}\text { Podocnemis } \\
\text { sextuberculata } \\
\text { Cornalia, } 1849\end{array}$ & $\begin{array}{l}\text { Six-tubercled } \\
\text { Amazon River } \\
\text { Turtle } \\
\end{array}$ \\
\hline $12^{o}$ & $\begin{array}{l}\text { Wild } \\
\text { animal }\end{array}$ & Aves & Emberizidae & $\begin{array}{c}\text { Zonotrichia capensis } \\
\text { (Statius Muller, } \\
1776)\end{array}$ & $\begin{array}{l}\text { Rufous-collared } \\
\text { Sparrow }\end{array}$ \\
\hline $13^{\underline{0}}$ & $\begin{array}{c}\text { Wild } \\
\text { animal }\end{array}$ & Aves & Emberizidae & $\begin{array}{c}\text { Sporophila nigricollis } \\
\text { (Vieillot, 1823) }\end{array}$ & $\begin{array}{c}\text { Yellow-bellied } \\
\text { Seedeater }\end{array}$ \\
\hline $14^{\mathrm{o}}$ & $\begin{array}{l}\text { Wild } \\
\text { animal }\end{array}$ & Aves & Emberizidae & $\begin{array}{l}\text { Sporophila collaris } \\
\text { (Boddaert, 1783) }\end{array}$ & $\begin{array}{c}\text { Rusty-collared } \\
\text { Seedeater }\end{array}$ \\
\hline $15^{\mathrm{o}}$ & $\begin{array}{c}\text { Wild } \\
\text { animal }\end{array}$ & Aves & Psittacidae & $\begin{array}{l}\text { Amazona aestiva } \\
\text { (Linnaeus, 1758) }\end{array}$ & $\begin{array}{c}\text { Blue-fronted } \\
\text { Parrot }\end{array}$ \\
\hline $16^{\mathrm{o}}$ & $\begin{array}{l}\text { Wild } \\
\text { animal }\end{array}$ & Reptilia & Alligatoridae & $\begin{array}{c}\text { Caiman crocodilus } \\
\text { (Linnaeus, } 1758 \\
\text { [originally Lacerta]) }\end{array}$ & $\begin{array}{l}\text { Common } \\
\text { Caiman }\end{array}$ \\
\hline $17^{\circ}$ & $\begin{array}{c}\text { Wild } \\
\text { animal }\end{array}$ & Aves & Turdidae & $\begin{array}{c}\text { Turdus rufiventris } \\
\text { Vieillot, } 1818 \\
\end{array}$ & $\begin{array}{c}\text { Rufous-bellied } \\
\text { Thrush }\end{array}$ \\
\hline $18^{\mathrm{o}}$ & $\begin{array}{c}\text { Wild } \\
\text { animal }\end{array}$ & Aves & Thraupidae & $\begin{array}{c}\text { Paroaria sp. } \\
\text { Bonaparte, } 1832\end{array}$ & Cardinal \\
\hline $19^{\circ}$ & $\begin{array}{l}\text { Wild } \\
\text { animal }\end{array}$ & Aves & --- & Not specified & Bird \\
\hline $20^{\circ}$ & $\begin{array}{c}\text { Wild } \\
\text { animal }\end{array}$ & Aves & Columbidae & $\begin{array}{l}\text { Zenaida auriculata } \\
\text { (Des Murs, 1847) }\end{array}$ & Eared Dove \\
\hline $21^{\circ}$ & $\begin{array}{c}\text { Wild } \\
\text { animal }\end{array}$ & Aves & Emberizidae & $\begin{array}{c}\text { Sporophila albogularis } \\
\text { (Spix, 1825) }\end{array}$ & $\begin{array}{c}\text { White-throated } \\
\text { Seedeater }\end{array}$ \\
\hline $22^{\circ}$ & $\begin{array}{c}\text { Domestic } \\
\text { animal }\end{array}$ & Mammalia & Bovidae & $\begin{array}{c}\text { Bos taurus } \\
\text { Linnaeus, } 1758\end{array}$ & Domestic Cattle \\
\hline $23^{\circ}$ & $\begin{array}{c}\text { Wild } \\
\text { animal }\end{array}$ & Aves & Psittacidae & Many species & Parrot \\
\hline $24^{\circ}$ & $\begin{array}{c}\text { Wild } \\
\text { animal }\end{array}$ & Aves & Fringillidae & $\begin{array}{c}\text { Sporagra magellanica } \\
\text { (Vieillot, 1805) }\end{array}$ & Hooded Siskin \\
\hline $25^{\mathrm{o}}$ & $\begin{array}{l}\text { Wild } \\
\text { animal }\end{array}$ & Reptilia & Podocnemididae & $\begin{array}{c}\text { Podocnemis unifilis } \\
\text { (Troschel, 1848) }\end{array}$ & $\begin{array}{c}\text { Yellow-spotted } \\
\text { Amazon River } \\
\text { Turtle } \\
\end{array}$ \\
\hline $26^{\mathrm{o}}$ & Wild & Aves & Icteridae & Icterus jamacaii & Campo Troupial \\
\hline
\end{tabular}




\begin{tabular}{|c|c|c|c|c|c|}
\hline Classif & Type & Class & Family & Specie $^{3}$ & Common name \\
\hline & animal & & & (Gmelin, 1788) & \\
\hline $27^{\circ}$ & $\begin{array}{l}\text { Wild } \\
\text { animal }\end{array}$ & Aves & Emberizidae & \begin{tabular}{|c|} 
Sporophila \\
maximiliani (Cabanis, \\
$1851)$
\end{tabular} & $\begin{array}{l}\text { Great-billed } \\
\text { Seed-Finch }\end{array}$ \\
\hline $28^{\circ}$ & $\begin{array}{l}\text { Wild } \\
\text { animal }\end{array}$ & Reptilia & Testudinidae & $\begin{array}{c}\text { Chelonoidis sp. } \\
\text { Fitzgerald, } 1835\end{array}$ & Tortoise \\
\hline $29^{\circ}$ & $\begin{array}{c}\text { Wild } \\
\text { animal }\end{array}$ & Aves & Turdidae & $\begin{array}{c}\text { Turdus sp. } \\
\text { Linnaeus, } 1758\end{array}$ & Thrush \\
\hline $30^{\circ}$ & $\begin{array}{l}\text { Wild } \\
\text { animal }\end{array}$ & Aves & Thraupidae & $\begin{array}{c}\text { Lanio cucullatus } \\
\text { (Statius Muller, } \\
\text { 1776) }\end{array}$ & $\begin{array}{c}\text { Red-crested } \\
\text { Finch }\end{array}$ \\
\hline
\end{tabular}

Table 4. Most confiscated species by IBAMA and partner institutions between 2005 and 2009.

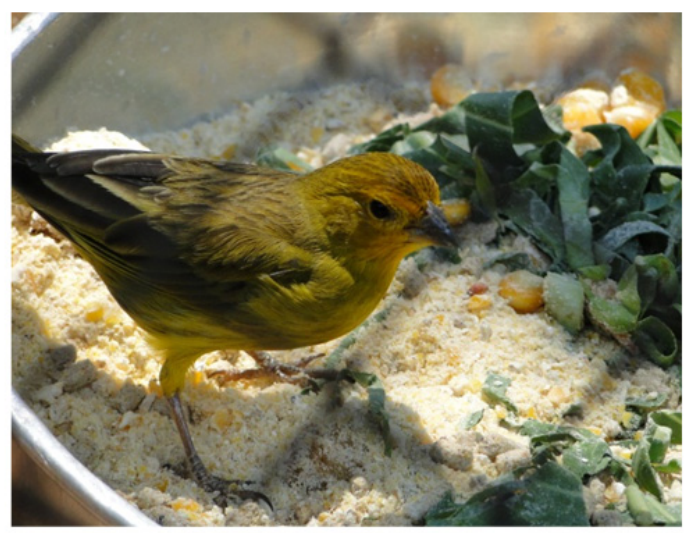

A

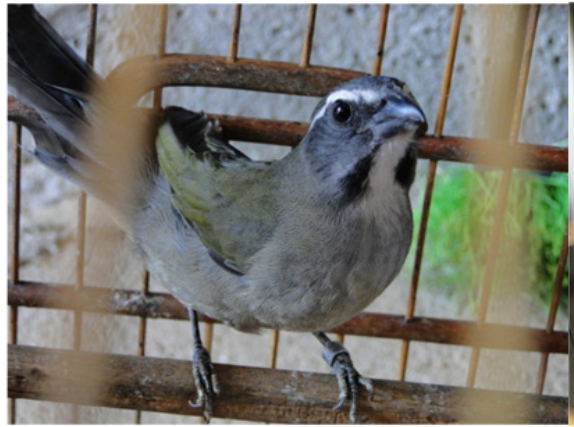

B

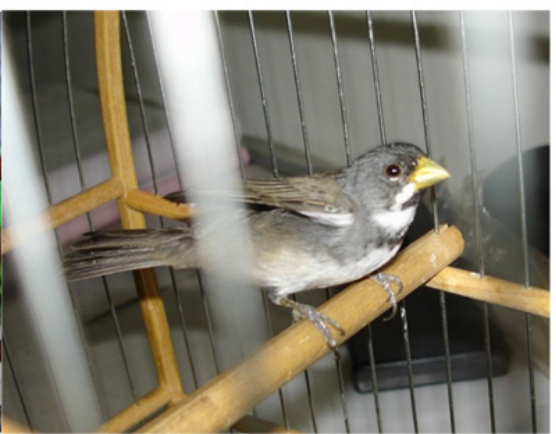

C

Figure 8. The three most confiscated species by environmental enforcement in Brasil: A. Sicalis flaveola (Saffron Finch), B. Saltator similis (Green-winged Saltator) and C. Sporophila caerulescens (Double-collared Seedeater). 
According to studies conducted by [8] in south Brazil, the most commonly confiscated species by enforcement, between 1998 and 2000, was the Cardinal (Paroaria coronata), followed by the Saffron Finch (Sicalis flaveola). And the Emberizidae family presented the largest number of seized specimens, compelling evidence that the great interests of the illegal trade are the songbirds.

The Emberizidae family also excelled in seizures conducted in southeastern and northeastern Brazil [7,10,11]. According to the authors, that fact can be explained, preliminarily, because that family has many species and specimens, for being abundant in the Neotropics, for having easy occurrence in the sampled region, for the high quality of its singing, due to its low market value and for being easy to maintain. Generally, the birds most wanted for trafficking are the songbirds or those able to become pets, confering them high values of trade [8].

Some species listed in Table 4 are exclusively Amazonian, as the Giant South American river turtle, Six-tubercled Amazon River turtle and Yellow-spotted Amazon River Turtle, all very popular in regional cuisine and found in nature in large populations. The domestic chicken (Gallus gallus) and domestic cattle (Bos taurus) obtained national prominence in seizures, because the first is often used in arenas, being the target of actions against animal abuse, and the second is the subject of crime in embargoed areas due to deforestation, mainly in the Amazon region.

We also observed an intrinsic relationship between the passerines authorized breeding and the wild animals trafficking: the five species more seized are also the taxa of greatest interest for commercial and amateur breeders of passerines (Table 5). All other passerines listed in Table 4 are species authorized for commercial and amateur activity.

\begin{tabular}{|c|c|c|c|c|}
\hline Classif. & Species $^{4}$ & Common name & $\begin{array}{c}\text { Total of } \\
\text { breeders }\end{array}$ & $\begin{array}{c}\text { Total of } \\
\text { specimens }\end{array}$ \\
\hline $1^{\mathrm{o}}$ & $\begin{array}{c}\text { Saltator similis } \\
\text { d'Orbigny \& Lafresnaye, } 1837\end{array}$ & Green-winged Saltator & 133.699 & 528.621 \\
\hline $2^{\underline{o}}$ & $\begin{array}{c}\text { Sporophila angolensis } \\
\text { (Linnaeus, 1766) }\end{array}$ & $\begin{array}{c}\text { Chestnut-bellied Seed- } \\
\text { Finch }\end{array}$ & 89.083 & 535.195 \\
\hline $3^{\mathrm{o}}$ & $\begin{array}{l}\text { Sporophila caerulescens } \\
\text { (Vieillot, 1823) }\end{array}$ & \begin{tabular}{|c|}
$\begin{array}{c}\text { Double-collared } \\
\text { Seedeater }\end{array}$ \\
\end{tabular} & 86.666 & 279.888 \\
\hline $4^{\mathrm{o}}$ & $\begin{array}{c}\text { Sicalis flaveola } \\
\text { (Linnaeus, 1766) }\end{array}$ & Saffron Finch & 83.281 & 444.160 \\
\hline $5^{\mathrm{o}}$ & $\begin{array}{l}\text { Cyanoloxia brissonii } \\
\text { (Lichtenstein, 1823) }\end{array}$ & Ultramarine Grosbeak & 46.364 & 108.703 \\
\hline $6^{\mathrm{o}}$ & $\begin{array}{l}\text { Sporagra magellanica } \\
\text { (Vieillot, 1805) }\end{array}$ & Hooded Siskin & 28.709 & 83.885 \\
\hline $7^{\circ}$ & $\begin{array}{c}\text { Turdus rufiventris } \\
\text { Vieillot, } 1818 \\
\end{array}$ & Rufous-bellied Thrush & 27.250 & 57.960 \\
\hline $8^{o}$ & $\begin{array}{c}\text { Saltator maximus } \\
\text { (Statius Muller, 1776) }\end{array}$ & Buff-throated Saltator & 19.129 & 53.203 \\
\hline
\end{tabular}

${ }^{4}$ Nomenclature according to the updated lists CBRO, 2011 (www.cbro.org.br) 


\begin{tabular}{|c|c|c|c|c|}
\hline Classif. & Species $^{4}$ & Common name & $\begin{array}{c}\text { Total of } \\
\text { breeders }\end{array}$ & $\begin{array}{c}\text { Total of } \\
\text { specimens }\end{array}$ \\
\hline $9^{\mathrm{o}}$ & $\begin{array}{l}\text { Sporophila maximiliani } \\
\text { (Cabanis, 1851) }\end{array}$ & $\begin{array}{l}\text { Great-billed Seed- } \\
\text { Finch }\end{array}$ & 18.142 & 123.832 \\
\hline $10^{\circ}$ & $\begin{array}{c}\text { Zonotrichia capensis } \\
\text { (Statius Muller, 1776) }\end{array}$ & $\begin{array}{c}\text { Rufous-collared } \\
\text { Sparrow }\end{array}$ & 16.466 & 32.677 \\
\hline $11^{\mathrm{o}}$ & $\begin{array}{l}\text { Sporophila lineola } \\
\text { (Linnaeus, 1758) }\end{array}$ & Lined Seedeater & 13.868 & 25.317 \\
\hline $12^{\mathrm{o}}$ & $\begin{array}{l}\text { Gnorimopsar chopi } \\
\text { (Vieillot, 1819) }\end{array}$ & Chopi Blackbird & 12.540 & 21.716 \\
\hline $13^{o}$ & $\begin{array}{l}\text { Cyanoloxia cyanoides } \\
\text { (Lafresnaye, 1847) }\end{array}$ & Blue-black Grosbeak & 11.435 & 23.435 \\
\hline $14^{\mathrm{o}}$ & $\begin{array}{c}\text { Paroaria coronata } \\
\text { (Miller, 1776) }\end{array}$ & Red-crested Cardinal & 11.310 & 33.110 \\
\hline $15^{\mathrm{o}}$ & $\begin{array}{l}\text { Sporophila frontalis } \\
\text { (Verreaux, 1869) }\end{array}$ & $\begin{array}{l}\text { Buffy-fronted } \\
\text { Seedeater }\end{array}$ & 9.301 & 22.073 \\
\hline $16^{\mathrm{o}}$ & $\begin{array}{l}\text { Sporophila nigricollis } \\
\text { (Vieillot, 1823) }\end{array}$ & $\begin{array}{l}\text { Yellow-bellied } \\
\text { Seedeater }\end{array}$ & 9.264 & 22.135 \\
\hline $17^{\mathrm{o}}$ & $\begin{array}{l}\text { Molothrus oryzivorus } \\
\text { (Gmelin, 1788) }\end{array}$ & Giant Cowbird & 8.878 & 18.858 \\
\hline $18^{\mathrm{o}}$ & $\begin{array}{c}\text { Lanio cucullatus } \\
\text { (Statius Muller, 1776) }\end{array}$ & Red-crested Finch & 6.922 & 13.635 \\
\hline $19^{\mathrm{o}}$ & $\begin{array}{l}\text { Saltator fuliginosus } \\
\text { (Daudin, 1800) }\end{array}$ & $\begin{array}{l}\text { Black-throated } \\
\text { Grosbeak }\end{array}$ & 6.756 & 14.533 \\
\hline $20^{\circ}$ & $\begin{array}{l}\text { Paroaria dominicana } \\
\text { (Linnaeus, 1758) }\end{array}$ & Red-cowled Cardinal & 6.123 & 11.675 \\
\hline
\end{tabular}

Table 5. Species of greatest interest to the passerine breeders in Brazil.

For [1], one of the ways to reduce the pressure on the populations for trafficking would be the encouragement of captive breeding programs to meet commercial demand. However, this strategy can be of great concern, since those animals cannot achieve the low prices offered by the trafficking [7].

\section{The trafficking routes}

In Figure 9 we grouped the main trafficking routes of wild animals in Brazil, including major airports, trade and source areas. We observed that, in general, the Brazilian fauna has been removed from the North, Northeast and Midwest of the Country and it is being sent to the Southeast, South and other regions of Northeast, by land or river, fuelling the national trade. In relation to the international illegal trade, we emphasize cities located in border regions in the North, Midwest and South of Brazil, as well as in ports and airports located in the Northern, Northeastern, Southern and Southeastern Brazilian regions.

For [1], beyond the States of Para (PA) and Amazonas (AM), which had national prominence in the amount of fines, other Amazonian frontiers must be of particular concern, 
such as the borders with the Guianas, Venezuela and Colombia, and the route of the Madeira River.

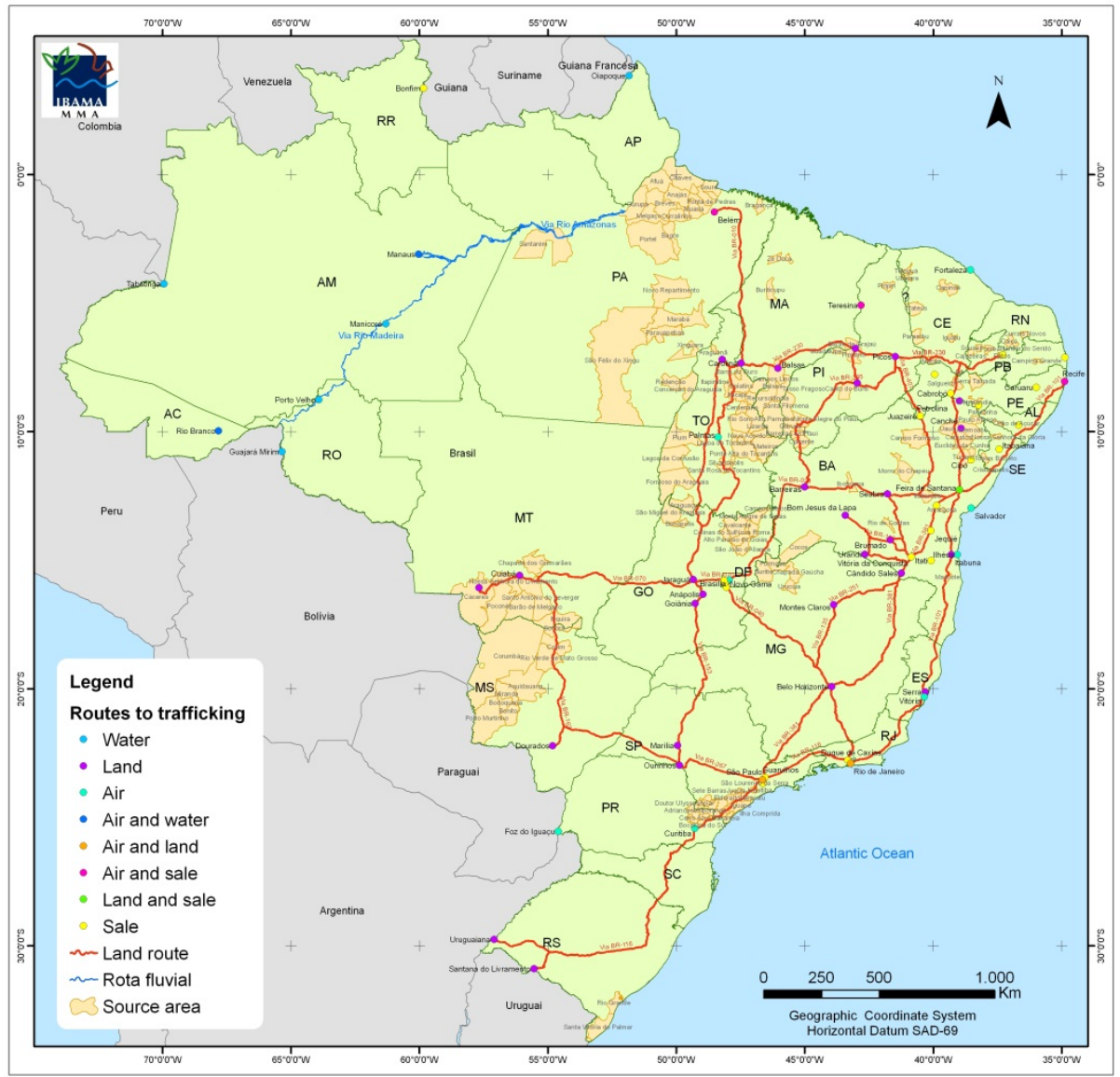

Figure 9. Main routes for the wild animals trafficking in Brazil.

The situation at the tri-border area (Brazil, Paraguay and Argentina) is also a matter of worry. According to [2], many animals are taken from the Iguaçu National Park and illegally sold during daylight or taken by peddlers to other Brazilian regions. Also in southern Brazil, the authors highlight as important areas for capturing and trading wild animals the towns of Laranjeiras do Sul (PR) and Santana do Livramento (RS), close to the border with Uruguay.

In [10], also emphasized the trafficking in the Southwest Bahia (BA) region, and they say that it is a socio-environmental problem with serious consequences to the local avifauna. According to them, the main trade in this region occurs along the BR-116 road, as well as in fairs and small shops roadside. 
Specialists point the absence of alternative income for people who use the trafficking as a means of livelihood. The report elaborated by the Brazilian National Congress in 2001 [12] recommends that the Union, States and Municipalities, in an articulated manner, must develop and implement programs to generate alternative income for poor communities involved in the illegal trade of wild animals.

However, the impact of trafficking in society needs to be further studied and its actors mapped. The capture of animals in nature is part of the culture and popular tradition, being one of the main livelihoods of the poor in some regions of Brazil [10]. However, in [11] found that in many regions people are using the illegal trade of animals only as an additional source of income. Thus, mechanism for control of wildlife use and trade should be formulated that take into consideration the special ethnic conditions of each region [13].

In global scale, it is recommended a multi-pronged approach including community-scale education and empowering local people to value wildlife, coordinated international regulation, and a greater allocation of national resources to on-the-ground enforcement for effective control of trafficking and illegal trade [9]. In Brazil, we noticed that the actions against illicit related to wildlife, although increasingly more organized and efficient, still require specific structural measures, among which we may highlight:

- Improving the number and the practice of IBAMA's agents and of Environmental Military Policeman through public competition and specific and continuous training;

- Increase the volume of public resources towards the activities of control and environmental monitoring;

- Increasing the incentive for the creation, implementation and maintenance of CETAS (Wild Animals Rehabilitation Centers);

- $\quad$ Reviewing the penal types of Law number 9.605/1998 due to provide harsher penalties for those who engage in wild animals trafficking such as large-scale commercial activity or international and interstate trafficking;

- Increasing responsibilities and sharing information among different agencies responsible for controlling and monitoring, through formal terms and shared systems;

- Maintening permanent negotiation between the federal government and neighboring countries through bilateral agreements, so that policies or environmental standards more flexible than the Brazilian ones are not used to support the illegal activities;

- Increasing the control over the sale of wild animals by internet and their exit to abroad through joint action among different government agencies such as IBAMA, the Federal Revenue Secretariat, Ministry of Health, Federal Police, etc..;

- Promoting Specific Environmental Education Campaigns aimed at minimizing the wild animals trafficking, as well as joint efforts among the various ministries involved, including the ones of Transport, Environment, Health and Tourism.

Lastly, we hope that this paper provides important and necessary subsidies for the decisionmaking to combat the animal trafficking in Brazil and abroad, helping the effective protection and conservation of the nature. 


\section{Conclusion}

We conclude that the Minas Gerais State was the largest contributor to the large volume of specimens seized in Brazil in the analized term, being Sicalis flaveola (Saffron Finch), Saltator similis (Green-winged Saltator) and Sporophila caerulescens (Double-collared Seedeater) the species most confiscated by environmental enforcement.

Furthermore, we noticed that releasing into the wild was the most common destination for mammals, birds and reptiles seized. The Wild Animals Rehabilitation Centers are essential support structures for the environmental enforcement actions related to fauna in Brazil.

\section{Author details}

Guilherme Fernando Gomes Destro, Tatiana Lucena Pimentel, Raquel Monti Sabaini, Roberto Cabral Borges and Raquel Barreto Coordination of Enforcement Operations, Brazilian Institute of Environment and Renewable Natural Resources - IBAMA. SCEN, Trecho II, Ed. Sede, Brasília/DF, Brazil

\section{References}

[1] RENCTAS (2011) Rede Nacional de Combate ao Tráfico de Animais Silvestres. $1^{\mathrm{o}}$ Relatório Nacional sobre o Tráfico de Fauna Silvestre. Available: http://www.renctas.org.br/. Acessed 2010 jul 15.

[2] Hernandez, E.F.T.; Carvalho, M.S. de. (2006) O tráfico de animais silvestres no Estado do Paraná. Acta Scientiarum: Human and Social Sciences, j. 28, n. 2: 257-266.

[3] Wasser, S.K.; Clark, W.J.; Drori, O.; Kisamo, E.S.; Mailand, C.; Mutayoba, B.; Stephens, M. (2008) Combating the Illegal Trade in African Elephant Ivory with DNA Forensics. Conservation Biology, j. 22, n. 4: 1065-1071.

[4] Alacs, E.; Georges, A. (2008) Wildlife across our borders: a review of the illegal trade in Australia. Australian Journal of Forensic Sciences. j. 40, n. 2: 147-160.

[5] Johnson, R.N. (2010). The use of DNA identification in prosecuting wildlife-traffickers in Australia: do the penalties fit the crimes? Forensic Scienci, Medicine and Pathology, j. 6: 211-216.

[6] Pavlin, B.I.; Schloegel, L.M.; Daszak, P. (2009) Risk of Importing Zoonotic Diseases through Wildlife Trade, United States. Emerging Infectious Diseases, j. 15, n. 11: 17211726.

[7] Borges, R.C.; Oliveira, A. de; Bernardo, N.; Martoni, R.; Costa, M.C. da. (2006) Diagnóstico da fauna silvestre apreendida e recolhida pela Polícia Militar de Meio Ambiente de Juiz de Fora, MG (1998 e 1999). Revista Brasileira de Zoociências, j. 8, n. 1: 23-33.

[8] Ferreira, C.M.; Glock, L. (2004) Diagnóstico preliminar sobre a avifauna traficada no Rio Grande do Sul, Brasil. Biociências, j. 12, n. 1: 21-30.

[9] Rosen, G.E.; Smith, K.F. (2010) Summarizing the evidence on the international trade in illegal wildlife. EcoHealth, j. 7: 24-32. 
[10] Souza, G.M. de; Soares Filho, A. de O. (2005) O comércio ilegal de aves silvestres na região do Paraguaçu e Sudoeste da Bahia. Enciclopédia Biosfera, j. 1: 1-10.

[11] Rocha, M. da S.P.; Cavalcanti, P.C. de M.; Souza, R. de L.; Alves, R.R. da N. (2006) Aspectos de comercialização ilegal de aves nas feiras livres de Campina Grande, Paraíba, Brasil. Revista de Biologia e Ciências da Terra, j. 6, n. 2: 204-221.

[12] BRASIL (2001) Comissão Parlamentar de Inquérito destinada a investigar o tráfico ilegal de animais e plantas silvestres da fauna e da flora brasileiras - cpitrafi. Relatório Final. Available: <http://www2.camara.gov.br/atividade-legislativa/comissoes/comissoes temporarias/parlamentar-de-inquerito/51-

legislatura/cpitrafi/relatorio/relatoriofinal.pdf $>$. Acessed 2010 sep 20.

[13] Yi-Ming L., Zenxiang, G.; Xinhai, L.; Sung, W.; Niemela, J. (2000) Illegal wildlife trade in the Himalayan region of China. Biodiversity and Conservation, j. 9: 901-918. 